\title{
THE IMPORTANCE OF QUINOA (QUINOA CHENOPODIUM WILLD.) CULTIVATION IN DEVELOPING COUNTRIES: A REVIEW
}

\author{
A. FATHI $^{1, *}$, F. KARDONI ${ }^{2}$ \\ *E-mail: dr.aminfathi@gmail.com
}

Received: June 13, 2020. Revised: Aug. 17, 2020. Accepted: Aug. 28, 2020. Published online: Oct. 16, 2020

\begin{abstract}
Quinoa is a dicotyledonous species for seeds and, therefore, is not known as a cereal grain and is a pseudograin, which is introduced nowadays as a new crop in the world. Population growth and the need for more food put additional pressure on the environment, especially on water resources and agronomic ecosystems. This has led to more attention to plants that grow at different latitudes and altitudes. Climatic and environmental changes affect agricultural inputs, especially water resources. So, the best way of adapting to the current situation is the introduction of low-water, saltresistant, and drought-tolerant plants to the recent climatic changes. Water scarcity has become a serious problem in many countries. This restriction has had a significant impact on the development of countries. The plants which grow in arid and semi-arid regions are often exposed to adverse environmental factors, such as drought or salinity. Salinity and drought stress, more than any other factor, decrease crop yields around the world.
\end{abstract}

These two abiotic stresses are the main limiting factors for crop production, especially in arid and semi-arid regions of the world. Quinoa is an exceptional plant that can adapt to adverse conditions and can serve as a solution to the challenge of global food security. Recent droughts that occurred in the world have prompted governments to include plants in their development plans, which are adapted to the country's existing water and soil conditions and have high nutritional value. This way, quinoa cultivation can ensure their food security in the coming years.

Keywords: food security; food value; global needs; drought; salt; nitrogen.

\section{INTRODUCTION}

Global agriculture faces many challenges, such as increasing population growth and food demand. The world's population is likely to reach more than 10 billion by 2050 ,

\footnotetext{
${ }^{1}$ Ayatollah Amoli Branch, Islamic Azad University, Amol, Iran

2 University of Birjand, South Khorasan Province, Birjand, Iran
} 


\section{A. FATHI, F. KARDONI}

with the world's food demand for agricultural land increasing rapidly (Tilman et al., 2011; Bouwman et al., 2017; Bai and Tao, 2017). The impacts of global climate change and its effect on the growth and productivity of crops are predicted to have significant economic impact on population and the environment worldwide (Jaikishun et al., 2019). A warm climate will be unsuitable for crop growth and yield since it reduces the soil's potential to capture and retain water and impound its fertility (González et al., 2015). These impacts will not only be detrimental to the environment but will cause tremendous strain on the entire ecosystem due to the many-sided source and variable effects. One of the significant problems emanating from these scenarios is food security, which is poised to reinforce progressively (FAO, 2019).

Drought, particularly in developing countries, poses a significant challenge for farmers, and in some areas, it is so severe that scientists are concerned with other farmers' lack of adaptability and resilience loss (Altieri and Nicholls, 2017; Imbach et al., 2017; Harvey et al., 2014; Hannah etal., 2017; Elum et al., 2017; Khatri-Chhetri et al., 2017). Therefore, the negative consequences of drought have become one of the main concerns of farmers in critical regions (Campell et al., 2011). Especially in societies with subsistence economies, i.e. smallscale farmers' communities as they are entirely dependent on their nature and agriculture (Endfield et al., 2004), drought stress reduces crop yields and depletes natural resources. Empowering farmers to cope with drought increases the security of nations to face the external threats and reduces the dependence of governments on other societies (Lipper et al., 2014; Steenwerth et al., 2014). In this regard, scholars and policymakers strongly emphasize the need for urgent action to prepare and adapt to the adverse effects of this phenomenon, especially in developing countries (IPCC, 2014). Because they understand the role of influencing factors on farmers' adaptation to ensure the development of appropriate policy measures and designing successful projects is vital for development (Gebrehiwot and Van der Veen, 2013). According to meet the growing needs of the increasing population, the introduction of plants with acceptable performance and resistance to stresses is necessary.

Quinoa is a pseudocereal and dicotyledonous seed belonging to the Amaranthaceae family, which in turn belongs to the Chenopodiaceae family. This family consists of economic species, such as spinach and beetroot (Jacobsen et al., 2003; VegaGálvez et al., 2010). Quinoa together with its wild relatives, including (Chenopodium carnosolum, C. petiolare, C. pallidicaule, C. quinoa melanospermum subsp., C. ambrosoides incisum) are a high diversity of species and applications (Fuentes et al., 2009). These species have traditionally been planted over the years by farmers from the Andes 
in Colombia, Ecuador, Peru, Bolivia, Chile, and Argentina. Quinoa is a dwarf plant with about $93 \%$ selfimmolation from the western Andean mountains of South America (Jacobsen et al., 2005; Bazile et al., 2014, 2015). To introduce the role and value of this plant in food security, the development of consumption and production, Food and Agriculture organization (FAO) named 2013 as the International Year of Quinoa (FAO, 2013). Quinoa is highly resistant against abiotic stresses, such as a wide range of cold, drought and salinity of the soli and also has an excellent ability to grow in marginal soils (Jacobsen et al., 2009; Hernández-Ledesma, 2019). Quinoa is considered a climate-resistant, gluten-free, highly nutritious seed product with remarkable agronomic adaptation to adverse climatic conditions (Dallagnol et al., 2013). The year 2013 was declared the year of quinoa by the United Nations, because these circumstances. Therefore, the goal of most countries in the world is to increase and evaluate the production of quinoa (Ruiz et al., 2016). The procurement of sustainable food in noxious environmental conditions, resulting from climate change scenarios for its credentials in nutritional composition and relevance was selected by NASA (National Aeronautics and Space Administration) as a preferred food for its astronauts on board space missions (Schlick and Bubenheim, 1993; Jaikishun et al., 2019).
This study shows that quinoa is of high nutritional value and is resistant to harsh environmental conditions (resistant to drought and salinity) to other crops. This plant has been introduced to the world since 2013 and requires extensive research in all regions of the world. Most of the developing countries have to cultivate plants that can meet their nutritional needs and grow properly in the climate of their areas.

\section{Distribution}

Worldwide, more than 6,000 varieties of plants have been grown by farmers (Rojas et al., 2015). Quinoa plant, with high nutritional value and high growth potential and production, grows in unfavorable conditions for many cultivated plants. Quinoa is resistant to climatic changes, and its seeds have a high protein content (Schoenlechner et al., 2010). In some parts of the world, quinoa is known as the "vegetable caviar" or the Inca rice. In the global distribution of quinoa production, Peru and Bolivia are the primary producers, in addition to USA, Ecuador, and Chile, Canada, Colombia, Argentina, and Mexico, which produce this plant mostly for local consumption (Fig. 1; FAO, 2011).

Quinoa has always been of great importance for many generations as an essential food for the people. In recent years, research and cultivation of this valuable plant have grown rapidly in the world. The reviews on the Google Scholar web site and the search for keywords, including quinoa, cultivation, agronomy, and 


\section{A. FATHI, F. KARDONI}

agricultural research, during 1970 and 2013 (over 43 years) have shown that near 3040 scientific reports have been presented about quinoa. However, from 2013 to March 2020, more than 4050 studies have been reported (for seven years).

The high adaptability of quinoa to various agro-climatic habitats and edaphic conditions has increased the yields of different varieties in countries outside South America, such as Europe, USA, Canada, China, and India (Gonzalez et al., 2012;
Jacobsen, 2011). The trend of changes in the area under cultivation and production during the years 1961 to 2018 is shown in Fig. 2.

Hence, the world production of quinoa has augmented in the past years and was near to 160,000 tonnes in 2018 (FAO, 2020). The trend of changes in the area under cultivation of quinoa has increased from 52555 hectares in 1961 to 178313 hectares in 2018.

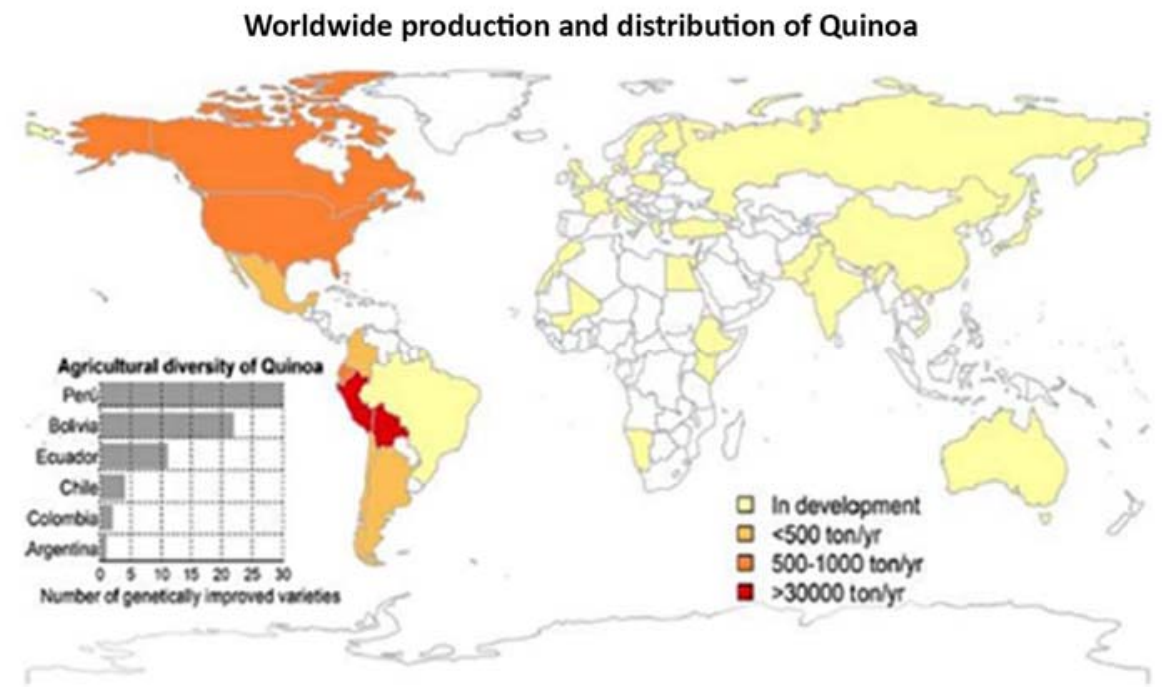

Figure 1 - Quinoa Production and Distribution Chart in the World (FAO, 2011)

\section{Importance of quinoa cultivation}

In recent years, rising food demand has led to population growth and the need for increased production, as well as broader use of agricultural lands (Xu et al., 2014; Jahani and Fathi, 2017). One of the factors contributing to crop growth in developed countries is recognizing the potential climate and climatic needs of plants and using them to increase efficiency (Kamali et al., 2010). Understanding the climatic parameters and their effects on plants are amongst the most critical factors in increasing yield and production (Kamali et al., 2010). The major part of the arable land is under stress, sometimes 
associated with drought and salt stress, which leads to the yield reduction of many crops (Fathi et al., 2017). Halophyte plants can grow in many areas, due to high adaptability to adverse environmental conditions (soil and water). Generally, environmental changes might reach critical levels in some areas and pose a severe threat to the quantitative and qualitative performance of agricultural products (Campbell et al., 2011; Fathi and Tari, 2016). The development and promotion of quinoa cultivation diversifies food products in the human nutrition basket. However, determining the compatibility, production rate, areas prone to cultivation with economic production and selecting appropriate cultivars are essential that require further research in this area.

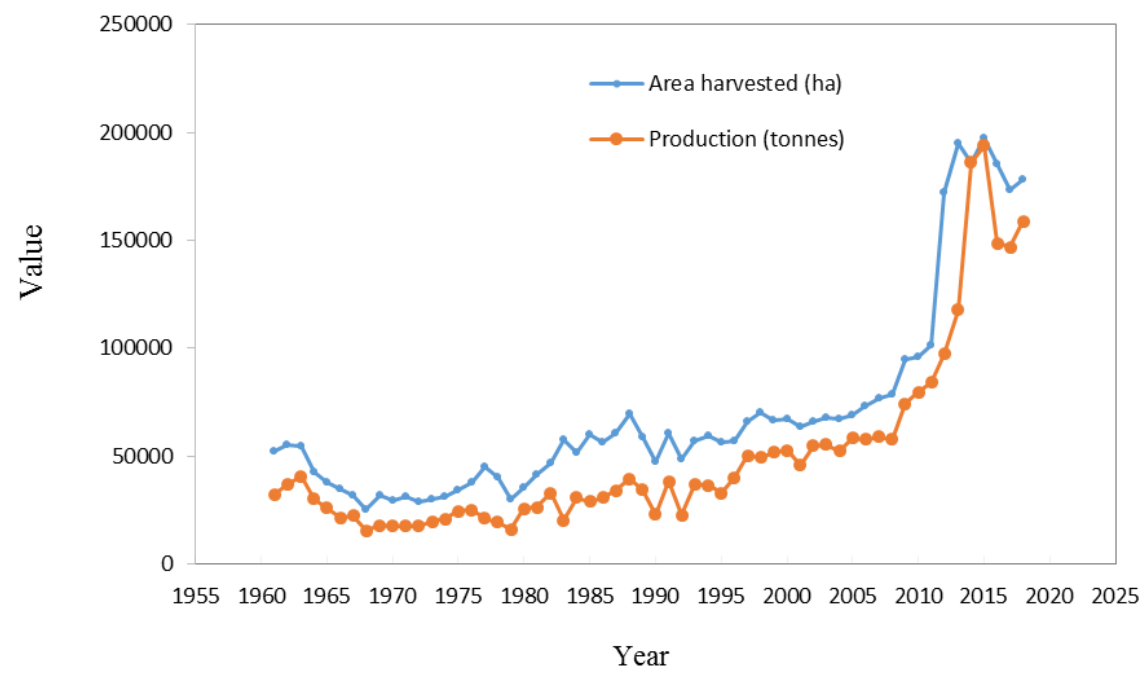

Figure 2 - Production and area harvested of Quinoa in World from 1961 to 2018 (FAO, 2020)

\section{Importance and nutritional value of quinoa}

Quinoa seeds are compact, digestible, and also a rich source of protein, iron, magnesium, fibers and vitamins. In comparison with standard grains, it has a higher protein content and more favorable amino acids (Zurita-Silva et al., 2014). Quinoa, exceptionally, has a very accurate balance between fats (4-9\%), protein (an average of $16 \%$ with high levels of essential amino acids) and carbohydrates (64\%) (Bhargava et al. 2006; Vega-Gálvez et al., 2010; Zurita-Silva et al., 2014). Quinoa is a vibrant source of vitamins and fats $(55-66 \%$ saturated fat), natural antioxidants, such as $\alpha-$ and $\gamma$ - tocopherol and a wide range of minerals (Mastebroek et al., 2000; Repo-Carrasco et al., 2003; Bhargava et al., 2006; Stikic et al., 2012). Quinoa seeds and leaves can be used to produce alcohol and drugs (antiinflammatory, analgesic and 


\section{A. FATHI, F. KARDONI}

disinfectant) and as insect repellents (Vega-Gálvez et al., 2010). In some countries, Quinoa is used as an alternative to meat and animal proteins (Jacobsen et al., 2003). Quinoa can also be used to produce drinks and salad alternatives. Grains play a significant role in the human diet by meeting nearly half of an individual's need for energy and protein intake. Wheat, rice, barley, corn, rye, and bean are the most crucial foods in the world, in human and animal diets. Quinoa is an excellent nutrient that has higher nutritional content than those of other grains. Quinoa's advantage over other grains results from its richer lipid, protein and ash content. A comparison of the quinoa chemistry and several plants is shown in Table 1.

Table 1 - Comparison of the nutritional values of grains and quinoa (edible $100 \mathrm{~g}$ )

\begin{tabular}{lccccccc}
\hline Clant & $\begin{array}{c}\text { Scientific } \\
\text { name }\end{array}$ & $\begin{array}{c}\text { Lipid } \\
(\mathbf{g})\end{array}$ & $\begin{array}{c}\text { Protein } \\
(\mathbf{g})\end{array}$ & $\begin{array}{c}\text { Ash } \\
(\mathbf{g})\end{array}$ & $\begin{array}{c}\text { Fiber } \\
(\mathbf{g})\end{array}$ & $\begin{array}{c}\text { Carbohydrate } \\
(\mathbf{g})\end{array}$ & $\begin{array}{c}\text { Energy } \\
(\mathbf{k c a l} / \mathbf{1 0 0 g})\end{array}$ \\
\hline Quinoa & $\begin{array}{c}\text { Chenopodium } \\
\text { quinoa }\end{array}$ & 6.07 & 14.12 & 2.7 & 7 & 64.16 & 368 \\
\hline Rice & Oryza sativa & 0.55 & 6.81 & 0.19 & 2.8 & 81.68 & 370 \\
\hline Wheat & $\begin{array}{c}\text { Triticum } \\
\text { aestivum L. }\end{array}$ & 2.47 & 13.68 & 1.13 & 10.7 & 71.13 & 339 \\
\hline Barley & $\begin{array}{c}\text { Hordeum } \\
\text { vulgare }\end{array}$ & 1.3 & 9.91 & 0.62 & 15.6 & 77.72 & 352 \\
\hline Maize & $\begin{array}{c}\text { Zea mays } \\
\text { Rye }\end{array}$ & 4.47 & 9.42 & 0.67 & 7.3 & 74.26 & 365 \\
\hline Secale & 1.63 & 10.34 & 0.98 & 15.1 & 75.86 & 368 \\
\hline montanum & $\begin{array}{c}\text { Phaseolus } \\
\text { vulgaris }\end{array}$ & 1.1 & 28 & 4.7 & 5 & 61.2 & 399 \\
\hline
\end{tabular}

Source: Navruz-Varli and Sanlier, 2016; Kozioł (1992)

\section{Grain protein}

The protein found in quinoa is more than that of the conventional cereals. But, its protein content is relatively lower than legumes protein. The protein content of quinoa seeds is variable in the range of $8 \%$ to $22 \%$, depending on the variety and growth conditions, with a higher percentage than grains such as wheat, barley, and rice (Jancurová et al., 2009). The protein content of quinoa is reported to be more than other cereals by Navruz-Varli and Sanlier (2016), as shown in Table 1. The exceptional characteristics of this plant have been made to be used as a portion of baby food for infants who do not use breast milk, especially in areas where there is a lack of nutrients (Matiacevich et al., 2006). The majority of the stored proteins in quinoa is composed of globulins (37\%) and albumins (35\%), it contains low concentrations of 
prolamins, and these percentages may vary in different species (James, 2009). Quinoa, which provides a protein value similar to casein in milk, contains essential amino acids (VegaGálvez et al., 2010). With its benefits close to those specified by FAO, its perfect amino acid balance and rich content with thionic amino acids and lysines. Quinoa is one of the plants that provide all the amino acids required for human life, and contrary to grain proteins that have negligible lysines, are accepted as high-quality proteins (Maradini Filho et al., 2015). Comai (2007) reported that quinoa had not only rich protein content, but also had a sufficiently high concentration of amino acid composition and tryptophan, which is generally the second limiting amino acid. Also, it contains a high amount of non-protein tryptophan that can be absorbed more efficiently and help increment the usability of this amino acid in the brain, thus having an influence on serotonin neurotransmitter synthesis (Comai, 2007).

\section{Carbohydrate}

Carbohydrates, according to their degree of polymerization, can be classified into three main groups: 1 sugars involving monosaccharides, disaccharides, and polysaccharides; 2 -oligosaccharides; 3 -polysaccharides containing starch and nonstarch (James, 2009). Quinoa is a deliberate part of carbohydrates, measured to $64 \%$ to $74 \%$ (dry basis) of dry matter (James et al., 2009). Starch is the main carbohydrate of quinoa, which is about $32-69 \%$. On the other hand, quinoa's nutritious fibers are similar to cereals and dissolve about 1.3-1.6\% of fibers (James et al., 2009). The role of food fibers is essential because of their specific characteristics, such as high water holding capacity, high capacity for ionic changes, the ability to absorb bile acids and toxic compounds and their effect on the growth of abundant intestinal microorganisms (Ruales and Nair, 1994). Useful and dissolved fibers of this seed have a positive impact on health, such as lowering blood cholesterol, improving digestion, and reducing blood glucose (ValenciaChamorro, 2003).

Because of its complete freezing stability, low gelling point and lowtemperature endurance, quinoa is an ideal thickener for soups, flours and sauces. Amylose content of quinoa starch varies between $3 \%$ and $22 \%$, which is lower than that of corn and wheat, higher than that of some kinds of barley, and similar to that of basic rice types (Navruz-Varli and Sanlier, 2016). In comparison to wheat and barley starch, quinoa starch has maximum viscosity, a higher water absorption capacity, and bigger swelling capacity. Besides, it has wonderful stability even in freezing and retro gradation processes (Tang et al., 2002). The following table shows carbohydrate compounds in quinoa, rice and barley (Table 2). 


\section{A. FATHI, F. KARDONI}

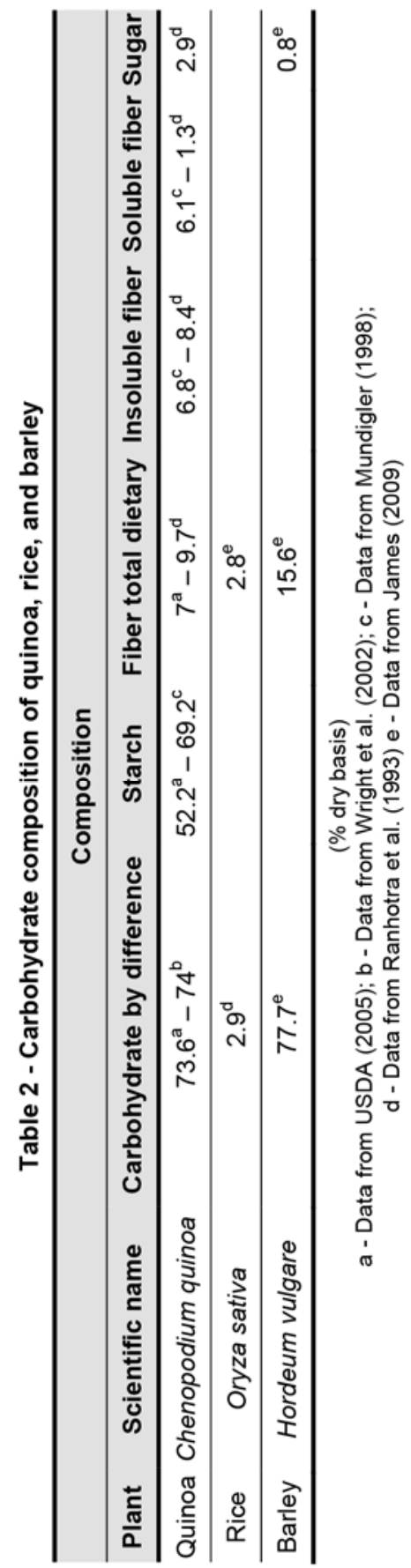

Carbohydrates from quinoa can evaluate a nutraceutical food since they have useful hypoglycemic impacts and induce the decrease of free fatty acids (James, 2009). Berti and co-workers (2004) reported that in a person with celiac disease, the glycemic index of quinoa was slightly lower than that of gluten-free bread and pasta. Moreover, quinoa induced lower free fatty acid levels than gluten-free pasta and significantly lower triglyceride concentrations, compared to gluten-free bread (Berti et al., 2004).

\section{Saponins}

Quinoa has an outer grain layer called saponin, which is toxic, has a bitter taste, and needs to be removed before the meal or during the food production process. Quinoa saponins are secondary metabolics that are distributed mostly in the crop and generally found in roots, leaves, seeds, stems, and fruits (Sparg et al., 2004). These layers have protective characteristics, i.e., they are produced for plant protection against harmful insects, microorganisms, and birds (Singh and Kaur, 2018). Saponins are divided into two main groups, steroid glycosides, and triterpenoid. Also, saponin varies by the position and numbers of sugar units linked to the xylose, hydrophobic aglycon, glucose, mainly arabinose, galactose, glucuronic acid, and rhamnose (Cheok et al., 2014). Saponins are a large group of plant glycosides containing about $0.01-5 \%$ of a dry weight basis (Kuljanabhagavad et al., 
2008; Ando et al., 2002). MedinaMeza et al. (2016) reported that quinoa contains 2 to $5 \%$ saponins in the form of oleanane-type triterpenoid glycosides or sapogenins found in the external layers of the seeds. Saponins is toxic to other organisms, but is commercially and industrially crucial for the preparation of soap and detergents. The bitter taste imparted by saponins could potentially be reduced by extrusion and roasting processes (Brady et al., 2007).

\section{Drought stress and quinoa}

Breeding crops to withstand drought has always had its problems. Therefore, in the first step, cultivation of drought-tolerant plants, such as quinoa, is one of the best ways of preventing crop yield decline so that they have less yield loss under identical conditions (Oelke et al., 1992; Vega-Gálvez et al., 2010; Hinojosa et al., 2018). The researchers showed that cultivation of different quinoa varieties in a wide range of climatic conditions, such as high or dry rainfall areas, cold or hot areas, areas $4000 \mathrm{~m}$ above sea level, US regions, Asia and Europe are highly adaptable (Jacobsen, 2003). Quinoa exhibits high resistance to a wide range of abiotic stresses, such as salinity and drought (Jacobsen et al., 2009; Adolf et al., 2013; Razzaghi et al., 2011). Hinojosa et al. (2018) reported that quinoa is a drought-tolerant crop capable of growing and producing seed in the semi-desert conditions of Chile, the arid mountains of northwestern Argentina, Peru and the
Altiplano, region of Bolivia. These environments are described as very dry, with less than $200 \mathrm{~mm}$ of annual rainfall (Aguilar and Jacobsen, 2003; Fuentes and Bhargava, 2011; Vacher, 1998).

However, the effects of drought stress vary depending on the type and moment of drought (Alandia et al., 2016). For quinoa, in semi-arid environments, the flowering stage is one of the most important and critical stages of life in response to drought stress (Geerts et al., 2008; He and Dijkstra, 2014; Jensen et al., 2000).

On the other hand, if the drought is accompanied by heat stress, it can have a negative impact on quinoa. Researchers reported that quinoa is particularly sensitive to high temperatures during flowering because it can damage the flower and reduce pollen viability (Jacobsen, 2003; Peterson and Murphy, 2015; Hinojosa et al., 2019). In a study by Hinojosa et al. (2018), it was found that the response of quinoa to elevated temperatures and other abiotic stresses varied depending on the variety and the combination of stressors. Many quinoa varieties show an increase in growth characteristics at higher temperatures but can suffer yield loss if combined with high temperatures with other stressors, such as low water availability or low relative humidity (Bazile et al., 2016; Hinojosa et al., 2018; Präger et al., 2018).

Results of drought stress analysis on quinoa seed yield reported that quinoa yield with $208 \mathrm{~mm}$ of water (irrigation and rainfall) was $1439 \mathrm{~kg} / \mathrm{ha}$ 


\section{A. FATHI, F. KARDONI}

(Oelke et al., 1992). However, it has been reported that quinoa irrigation in arid regions has a higher yield (Martínez et al., 2009). The quinoa plant protects osmotic potential from drought stress by increasing betaine and polyamines and, consequently, its yield is less affected (Ruiz-Carrasco et al., 2011).

Pulvento et al. (2012) reported that grain yield of quinoa (Titicaca) ranged between $2300-2700 \mathrm{~kg} / \mathrm{ha}^{-1}$, during the growing season, whether under high irrigation $(300-360 \mathrm{~mm})$ or deficit irrigation (200-220 mm).

Al-Naggar et al. (2017), in Egypt, have evaluated five quinoa genotypes under three different growing season and water regimes, consisting of low $(236 \mathrm{~mm})$, moderate $(500 \mathrm{~mm})$ and high $(820 \mathrm{~mm})$ irrigation treatments (irrigation + rainfall). They showed high variability in morphological traits and yield among genotypes across the different water regimes. For example, sea-level variety 'QL-3' exhibited the most significant reduction in yield $(56 \%)$ under severe stress; valley variety 'CICA-17' showed the smallest decrease (12\%). Based on the survey, it can be concluded that: 1. Quinoa is resistant to drought; 2. During drought stress, if another stress occurs, it will cause severe yield loss; 3 . The timing of drought stress is important in the growth stages of quinoa; 4 . The response of cultivars to drought stress varies. It seems that due to the different reactions of quinoa cultivars to drought stress, this plant can be used in areas with water scarcity, and since quinoa has shown good resistance to drought stress, more research is needed to determine the resistance of quinoa to drought stress.

\section{Salt stress and quinoa}

After drought stress in plants, salinity is one of the major agricultural problems in arid and semi-arid regions. High salinity is considered as one of the substantial abiotic stresses that limit crop production because it causes reduced respiration, photosynthesis and protein synthesis (Hinojosa et al., 2018).

Photosynthesis reduction, nutrient imbalance, membrane denaturalization, stomatal closure, and a dramatic increase in reactive oxygen species (ROS) production are the basic physiological changes in crop under salt stress (Gupta et al., 2014; Munns et al., 2015). High accumulations of ROS cause severe crop toxicity, including the oxidative damage in lipids proteins, proteins, and DNA; but, low concentrations of ROS act as signaling molecules (Miller et al., 2010; Sharma et al., 2012; Hinojosa et al., 2018). However, many members of the Chenopodiaceae family are classified as salt-tolerant (Wilson et al., 2002). In the halophytes plant, the seedling and germination stages are the most sensitive stages to the salinity (Debez et al., 2004; Gul et al., 2013). In fact, after passing through the emergence stage, quinoa has a high tolerance to salinity stress. Studies have shown that quinoa can withstand 
these conditions and grow in poor soils (Wilson et al., 2002).

The researchers reported that the optimal salinity conditions for quinoa growth are between 100 to $200 \mathrm{mM}$ of $\mathrm{NaCl}$ (Sun et al., 2017; Eisa et al., 2017; Hariadi et al., 2011). Quinoa is an optional plant that is able to withstand sea surface salinity $\left(40 \mathrm{dS} / \mathrm{m}^{-1}\right)$ (Adolf et al., 2013). A study has shown that with saline irrigation water as high as $40 \mathrm{dS} / \mathrm{m}$, a yield reduction of only $50 \%$ will occur (Razzaghi et al., 2011). Studies have shown that some quinoa cultivars are able to complete their lifespan at $50 \mathrm{dS} / \mathrm{m}$. The presence of salt bags on the surface and under the quinoa leaves and their excretion of salt is one of the plant's strategies for combating salinity (Koyro et al., 2008).

\section{Nitrogen ( $N$ ) fertilizer and quinoa}

The tendency of the international community towards sustainable agriculture is to reduce the use of various inputs, especially chemical feedstocks, with the ultimate goal of achieving sustainable performance and reducing adverse environmental impacts. $\mathrm{N}$ is the main limiting factor for crop production, especially in arid and semi-arid regions, and therefore is widely used as a chemical fertilizer (Semenov et al., 2007; Ichie et al., 2002). N plays an essential role in achieving high quantitative and qualitative yields in crops (Zhao et al., 2003; Cassman et al., 2003) and is involved in the formation of amino acids, vitamins, and chlorophyll. If sufficient $\mathrm{N}$ is available to the plant, it will increase the growth rate of the plant and store the protein content of the seed (Zeidali et al., 2018; Karami et al., 2018; Khan et al., 2011).

$\mathrm{N}$ is one of the most important elements for plant growth. Researchers reported that quinoa reacts strongly to the $\mathrm{N}$ fertilizer (Schulte auf'm Erley et al., 2005). However, it should be noted that $\mathrm{N}$ fertilizer should not be overconsumed. Research has shown that excessive application of $\mathrm{N}$ fertilizer increases the length of the vegetative period and delays the reproductive phase (Marschner, 2011). It seems that split and optimum use of $\mathrm{N}$ fertilizer can have an impact on increasing crop yield. In an experiment in Europe, the yield of quinoa was obtained by consuming $120 \mathrm{~N} \mathrm{~kg} / \mathrm{ha}^{-1}$ at $3500 \mathrm{~kg} / \mathrm{ha}^{-1}$ (Schulte auf'm Erley et al., 2005). Berti et al. (2000) reported the highest grain yield of quinoa with the highest $\mathrm{N}$ utilization $\left(225 \mathrm{~kg} / \mathrm{ha}^{-1}\right)$. Excessive amounts of $\mathrm{N}$ decrease grain yield, as it slows down maturity and increases vegetative growth. $\mathrm{N}$ fertilizer application increases grain yield and its protein content (Williams and Brenner, 1995). Gomaa (2013) reported that $\mathrm{N}$ fertilizer increased vegetative growth and metabolic process in quinoa, as well as the accumulation of the plant dry matter.

The results of an experiment conducted at Izmir University in Turkey, for the effect of different levels of $\mathrm{N}$ fertilizer on grain yield in 


\section{A. FATHI, F. KARDONI}

Mediterranean climates, showed that the best amount of $\mathrm{N}$ for maximum grain yield, harvest index, and 1000 -grain weight, was $150 \mathrm{~kg} / \mathrm{ha}^{-1}$ (Geren, 2015). In another experiment, it was reported that the best $\mathrm{N}$ level for quinoa was $120 \mathrm{~kg} / \mathrm{ha}^{-1}$ (Mosseddaq et al., 2016). Generally, the $\mathrm{N}$ consumption rate is different for each climate and region. Nevertheless, according to the studies, it can be stated that the recommended $\mathrm{N}$ fertilizer for quinoa is about 100 to $200 \mathrm{~kg} / \mathrm{ha}^{-1}$. However, this may increase in some areas.

\section{CONCLUSIONS}

Population growth and the need for more food put additional pressure on the environment, especially on water resources and agronomic ecosystems. This has led to more attention to plants that grow at different latitudes and altitudes. Climatic and environmental changes affect agricultural inputs, especially water resources. So, the best way of adapting to the current situation is the introduction of low-water, saltresistant, and drought-tolerant plants to the recent climatic changes.

Quinoa has recently been considered as a food source due to its resistance to drought, salinity, and high nutritive value in terms of protein, essential amino acids, vitamins, and essential elements. The amount of required amino acids in quinoa seed protein is high, and the main application of using quinoa is a food supplement, due to its response to the growing international demand for gluten-free products. The seeds of this plant are abundant in preparing sweets, biscuits, salads, all kinds of food, as well as cereal flour enrichment. Quinoa is a resistant plant that can be grown in poor soil. This plant is an excellent economic alternative for the agricultural sectors. The superior adaptability of quinoa under different climatic and terrestrial conditions has led to cultivating such plants in many parts of the world to address the problems of malnutrition and starvation.

\section{REFERENCES}

Adolf, V.I., Jacobsen, S.-E. \& Shabala, S. (2013). Salt tolerance mechanisms in quinoa (Chenopodium quinoa Willd.). Environ.Exp.Bot., 92: 43-54, DOI: 10.1016/j.envexpbot.2012.07.004

Aguilar, P.C. \& Jacobsen, S.-E. (2003). Cultivation of quinoa on the Peruvian Altiplano. Food Rev.Int., 19(1-2): 3141, DOI: $10.1081 / F R I-120018866$

Alandia, G., Jacobsen, S.-E., Kyvsgaard, N.C., Condori, B. \& Liu, F. (2016). Nitrogen sustains seed yield of quinoa under intermediate drought. J.Agron. Crop Sci., 202(4): 281-291, DOI: $10.1111 /$ jac. 12155

Al-Naggar, A.M.M., Abd El-Salam, R.M., Badran, A.E.E. \& El-Moghazi, M.A. (2017). Genotype and drought effects on morphological, physiological and yield traits of quinoa (Chenopodium quinoa Willd.). Asian J.Adv.Agric.Res., 3(1): 1-15, DOI: 10.9734/AJAAR/2017/ 36655

Altieri, M.A. \& Nicholls, C I. (2017). The adaptation and mitigation potential of traditional agriculture in a changing climate. Clim. Change, 140(1): 33-45, DOI: 10.1007/s10584-013-0909-y 
Ando, H., Chen, Y.C., Tang, H., Shimizu, M., Watanabe, K. \& Mitsunaga, T. (2002). Food components in fractions of quinoa seed. Food Sci.Technol.Res., 8(1): 80-84, DOI: 10.3136/fstr.8.80

Bai, H. \& Tao, F. (2017). Sustainable intensification options to improve yield potential and eco-efficiency for ricewheat rotation system in China. Field Crops Res., 211: 89-105, DOI: 10.1016/j.fcr.2017.06.010

Bazile, D., Martinez, E.A. \& Fuentes, F. (2014). Diversity of quinoa in a biogeographical Island: a review of constraints and potential from arid to temperate regions of Chile. Not.Bot. Horti.Agrobot. Cluj-Napoca, 42: 289298, DOI: $10.15835 / \mathrm{nbha}$.42.2.9733

Bazile, D., Bertero, H. D. \& Nieto, C. (Eds.). (2015). State of the art report on quinoa around the world in 2013. Rome: FAO; CIRAD. Available online at: http://www.fao.org/3/a-i40 42e.pdf

Bazile, D., Pulvento, C., Verniau, A., AlNusairi, M.S., Ba, D., Breidy, J., Hassan, L., Mohammed, M.I., Membetoc, O., Otabekova, M. \& Padulosi, S. (2016). Worldwide evaluations of quinoa: preliminary results from post international year of quinoa $\mathrm{FAO}$ projects in nine countries. Front. Plant Sci., 7: 850, DOI: 10.3389/fpls.2016.00850

Berti, M., Wilckens, R., Hevia, F., Serri, H., Vidal, I. \& Méndez, C. (2000). Fertilización nitrogenada en quínoa (Chenopodium quinoa Willd). Cienc. Investig.Agrar., 27(2): 81-90, DOI: 10.7764/rcia.v27i2.999

Berti, C., Riso, P. Monti, L. \& Porrini, M. (2004). In vitro starch digestibility and in vivo glucose response of gluten-free foods and their gluten counterparts. Eur.J.Nutr., 43(4): 198204, DOI: 10.1007/s00394-004-04 59-1

Bhargava, A., Shukla, S. \& Ohri, D. (2006). Chenopodium quinoa - an Indian perspective. Ind. Crops Prod.,
23(1):73-87, DOI: 10.1016/j.indcrop. 2005.04.002

Bouwman, A.F., Beusen, A.H., Lassaletta, L., van Apeldoorn,D.F., van Grinsven, H.J., Zhang, J. \& Ittersum van, M.K. (2017). Lessons from temporal and spatial patterns in global use of $\mathrm{N}$ and $\mathrm{P}$ fertilizer on cropland. Sci.Rep., 7(1): 40366, DOI: 10.1038/srep40366

Brady, K., Hoa, Ch., Rosen, R., Sanga, S. \& Karwe, M. (2007). Effects of processing on the nutraceutical profile of quinoa. Food Chem., 100(3): 1209-1216, DOI: 10.1016/ j.foodchem.2005.12.001

Campbell, D., Barker, D. \& McGregor, D. (2011). Dealing with drought: small farmers and environmental hazards in southern St. Elizabeth, Jamaica. Appl.Geogr., 31(1): 146-158, DOI: 10.1016/j.apgeog.2010.03.007

Cassman, K.G., Dobermann, A., Walters, D.T. \& Yang, H. (2003). Meeting cereal demand while protecting natural resources and improving environmental quality. Annu.Rev.Environ.Res., 28: 315358, DOI: 10.1146/annurev.energy. 28.040202.122858

Cheok, C.Y., Salman, H.A.K. \& Sulaiman, R. (2014). Extraction and quantification of saponins: a review. Food Res.Int., 59: 16-40, DOI: 10.1016/j.foodres.2014.01.057

Comai, S. (2007). The content of proteic and nonproteic (free and proteinbound) tryptophan in quinoa and cereal flours. Food Chem., 100(4): 1350-1355, DOI: 10.1016/j.food chem.2005.10.072

Dallagnol, A.M., Pescuma, M., De Valdez, G.F. \& Rollán, G. (2013). Fermentation of quinoa and wheat slurries by Lactobacillus plantarum CRL 778: proteolytic activity. App.Microbial.Biotechnol., $\quad$ 97(7): 3129-3140, DOI: 10.1007/s00253012-4520-3

Debez, A., Hamed, K.B., Grignon, C. \& Abdelly, C. (2004). Salinity effects 


\section{A. FATHI, F. KARDONI}

on germination, growth, and seed production of the halophyte Cakile maritima. Plant Soil, 262(1-2): 179189, DOI: 10.1023/B:PLSO.00000 37034.47247 .67

Eisa, S.S., Eid, M.A., Abd El-Samad, E.H., Hussin, S.A., Abdel-Ati, A.A., \& El-Naggar, A.M. (2017). Chenopodium quinoa Willd. A new cash crop halophyte for saline regions of Egypt. Aust.J. Crop Sci., 11(3): 343-351, DOI: 10.21475/ajcs. 17.11.03.pne316

Elum, Z.A., Modise, D.M. \& Marr, A. (2017). Farmer's perception of climate change and responsive strategies in three selected provinces of South Africa. Clim. Risk Manag., 16: 246-257, DOI: 10.1016/ j.crm.2016.11.001

Endfield, G.H., Tejedo, I.F. \& O'Hara, S.L. (2004). Drought and disputes, deluge and dearth: climatic variability and human response in colonial Oaxaca, Mexico. J.Hist.Geogr., 30(2): 249-276, DOI: 10.1016/s0305-7488(03)00023-9

FAO (2011). The state of food insecurity in the world. Food and Agriculture Organization of the United Nations, Rome. http//:www.fao.org/docrep/ 014/i2330e/i2330e.pdf. Accessed 4 Oct 2013.

FAO (2013). Home-international year of quinoa 2013. Retrieved 21 February 2014, from http://www.fao.org/ quinoa-2013/en/.

FAO (2019). International Fund for Agricultural Development (IFAD); United Nations Children's Fund (UNICEF); World Food Programme (WFP); World Health Organization (WHO). The State of Food Security and Nutrition in the World 2018. Building Climate Resilience for Food Security and Nutrition; FAO: Rome, Italy, 2018; Available online: http://www.fao.org/3/i9553en/i9553e n.pdf (accessed on 1 January 2019).

FAO, 2020. The State of Food Security and Nutrition in the World 2020 Launch (https://sustainabledevelop ment.un.org/index.php?page =view\&t ype $=20000 \& n r=6909 \&$ menu=2993).

Fathi, A., Kianersi, F. Azizi, H. \& Bahamin, S. (2017). Effect of bio fertilizers and environmental stresses on medicinal plants (problems, benefits and solutions). Tehran Dibagaran Press, p. 242.

Fathi, A. \& Tari, D.B. (2016). Effect of drought stress and its mechanism in plants. Int.J. Life Sci., 10(1): 1-6, DOI: 10.3126/ijls.v10i1.14509

Foladvand, F., Khoshkhabar, H., Naghdi, N., Hosseinabadi, M., Bahamin, S. \& Fathi, A. (2017). The effect of sowing date and nitrogen on yield, and essential oil of German chamomile. Scientia, 19(3): 85-92.

Fuentes, F.F., Martinez, E.A., Hinrichsen, P.V., Jellen, E.N. \& Maughan, P.J. (2009). Assessment of genetic diversity patterns in Chilean quinoa (Chenopodium quinoa Willd.) germplasm using multiplex fluorescent microsatellite markers. Conserv.Genet., 10(2), 369-377, DOI: 10.1007/s10592-0089604-3

Fuentes, F. \& Bhargava, A. (2011). Morphological analysis of quinoa germplasm grown under lowland desert conditions. J.Agron. Crop Sci., 197(2): 124-134, DOI: 10.1111/ j.1439-037X.2010.00445.X

Gebrehiwot, T. \& van Der Veen, A. (2013). Farm level adaptation to climate change: the case of farmer's in the Ethiopian Highlands. Environ. Manag., 52(1): 29-44, DOI: 10.1007/ s00267-013-0039-3

Geerts, S., Raes, D., Garcia, M., Vacher, J., Mamani \& Taboada, C. (2008). Introducing deficit irrigation to stabilize yields of quinoa (Chenopodium quinoa Willd.). Eur.J.Agron., 28(3): 427-436, DOI: 10.1016/j.eja.2007.11.008

Geren, H. (2015). Effects of different nitrogen levels on the grain yield and some yield components of quinoa (Chenopodium quinoa Willd.) under 
Mediterranean climatic conditions. Turkish J.Field Crop., 20(1): 59-64, DOI: $10.17557 / .39586$

Gomaa, E.F. (2013). Effect of nitrogen, phosphorus and biofertilizers on quinoa plant. J.Appl.Sci.Res., 9(8): 5210-5222.

González, J.A., Konishi, Y., Bruno, M., Valoy, M. \& Prado, F.E. (2012). Interrelationships among seed yield, total protein and amino acid composition of ten quinoa (Chenopodium quinoa) cultivars from two different agroecological regions. J.Sci. Food Agric., 92(6): 1222-1229, DOI: 10.1002/jsfa.4686

González, J.A., Eisa, S., Hussin, S. \& Prado, F.E. (2015). Quinoa: an incan crop to face global changes in agriculture. Quinoa. in book: Improvement and Sustainable production, 1st ed., ch. 1, John Wiley \& Sons, Inc., Eds.: Kevin Murphy, Janet Matanguihan, pp. 1-18, DOI: 10.1002/9781118628041.ch1P

Gul, B., Ansari, R., Flowers, T.J. \& Khan, M.A. (2013). Germination strategies of halophyte seeds under salinity. Environ.Exp.Bot., 92: 4-18, DOI: $10.1016 /$ j.envexpbot.2012.11. 006

Gupta, B. \& Huang, B. (2014). Mechanism of salinity tolerance in plants: physiological, biochemical, and molecular characterization. Int.J.Genom., 1:701596, DOI: 10. 1155/2014/701596

Hannah, L., Donatti, C. I., Harvey, C. A., Alfaro, E., Rodriguez, D. A., ...\& Solano, A.L. (2017). Regional modeling of climate change impacts on smallholder agriculture and ecosystems in Central America. Clim. Change, 141(1): 29-45, DOI: 10.1007/s10584-016-1867-y

Hariadi, Y., Marandon, K., Tian, Y., Jacobsen, S.E. \& Shabala, S. (2011). Ionic and osmotic relations in quinoa (Chenopodium quinoa Willd.) plants grown at various salinity levels. J.Exp.Bot., 62(1): 185-193, DOI: $10.1093 / j x b / e r q 257$
Harvey, C.A., Rakotobe, Z.L., Rao, N.S., Dave, R., Razafimahatratra, H., Rabarijohn, R.H., ... \& MacKinnon, J.L. (2014). Extreme vulnerability of smallholder farmers to agricultural risks and climate change in Madagascar. Philos.Trans. Royal Soc.Lond.B.Biol.Sci., 369(1639): 1-12, DOI: $10.1098 /$ rstb.2013.0089

He, M. \& Dijkstra, F.A. (2014). Drought effect on plant nitrogen and phosphorus: a meta-analysis. New Phytol., 204(4): 924-931, DOI: 10.1111/nph.12952

Hernández-Ledesma, B. (2019). Quinoa (Chenopodium quinoa Willd.) as source of bioactive compounds: a review. BCHD Journal, 2(3): 27, DOI: 10.31989/bchd.v2i3.556

Hinojosa, L., González, J.A., BarriosMasias, F H., Fuentes, F. \& Murphy, K.M. (2018). Quinoa abiotic stress responses: A review. Plants, 7(4): 106, DOI: 10.3390/ plants7040106

Hinojosa, L., Matanguihan, J. \& Murphy, K.M. (2019). Effect of high temperature on pollen morphology, plant growth and seed yield in quinoa (Chenopodium quinoa Willd.). J.Agron. Crop Sci., 20(1): 3345, DOI: 10.1111/jac.12302

Ichie, T., Kitahashi, Y., Matsuki, S., Maruyama, Y. \& Koike, T. (2002). The use of a portable nondestructive type nitrogen meter for leaves of woody plants in field studies. Photosynthetica, 40(2): 289292, DOI:10.1023/A:1021362127882

Imbach, P., Beardsley, M., Bouroncle, C., Medellín, C., Läderach, P. \& Donatti, C.I. (2017). Climate change, ecosystems and smallholder agriculture: an introduction to the special issue. Clim. Change, 141(1): 1-12, DOI: 10.1007/s10584-0171920-5

IPCC (2014). Climate change, 2014: Synthesis Report. Contribution of Working Groups I, II and III to the Fifth Assessment Report of the Intergovernmental Panel on Climate 


\section{A. FATHI, F. KARDONI}

Change [Core Writing Team, R.K. Pachauri and L.A. Meyer (eds.)], IPCC, Geneva, Switzerland, 151 p. The Synthesis Report of the Fifth Assessment Report of the Intergovernmental Panel on Climate Change (IPCC).

Jacobsen, S.E. (2003). The worldwide potential for quinoa (Chenopodium quinoa Willd.). Food Rev.Int., 19(1-2): 167-177, DOI: 10.1081/FRI120018883

Jacobsen, S.E., Mujica, A. \& Jensen, C.R. (2003). The resistance of quinoa (Chenopodium quinoa Willd.) to adverse abiotic factors. Food Rev.Int., 19(1-2): 99-109, DOI: 10.1081/FRI-120018872

Jacobsen, S.E., Monteros, C., Christiansen, J.L., Bravo, L.A., Corcuera, L.J. \& Mujica, A. (2005). Plant responses of quinoa (Chenopodium quinoa Willd.) to frost at various phenological stages. European Journal of Agronomy, 22(2): 131-139, DOI: 10.1016/j.eja. 2004.01.003

Jacobsen, S. E., Monteros, C., Christiansen, J. L., Bravo, L. A., Corcuera, L. J. \& Mujica, A. (2005). Plant responses of quinoa (Chenopodium quinoa Willd.) to frost at various phenological stages. Eur.J.Agron., 22(2), 131-139.

Jacobsen, S.E., Liu, F. \& Jensen, C.R. (2009). Does root-sourced ABA play a role for regulation of stomata under drought in quinoa (Chenopodium quinoa Willd.). Sci.Hortic., 122(2): 281-287, DOI: 10.1016/j.scienta.2009.05.019

Jacobsen, S.E. (2011). The situation for quinoa and its production in southern Bolivia: from economic success to environmental disaster. J.Agron.Crop Sci., 197(5): 390-399, DOI: $10.1111 /$ j.1439-037X.2011.004 75.x

Jahani, F. \& Fathi. A. (2017). Drought stress in crops. Arshadan Press, p. 104, Tehran, Iran.
Jaikishun, S., Li, W., Yang, Z. \& Song, S. (2019). Quinoa: in perspective of global challenges. Agron., 9(4): 176, DOI: $10.3390 /$ agronomy 9040176

James, L.E.A. (2009). Quinoa (Chenopodium quinoa Willd.): composition, chemistry, nutritional, and functional properties. Adv. Food Nutr.Res., 58: 1-31, DOI: 10.1016/ S1043-4526(09)58001-1

Jancurová, M., Minarovičová, L. \& Dandár, A. (2009). Quinoa - a review. Czech J. Food Sci., 27(2): 71-79, DOI: 10.17221/32/2008-CJFS Jensen, C.R., Jacobsen, S.-E., Andersen, M.N., Núñez, N., Andersen, S.D., Rasmussen, L. \& Mogensen, V.O. (2000). Leaf gas exchange and water relation characteristics of field quinoa (Chenopodium quinoa Willd.) During soil drying. Eur.J.Agron., 13(1): 1125, DOI: 10.1016/S1161-0301(00) 00055-1

Kamali, G.A., Molaei, P. \& Behyar, M.B. (2011). Development of Zanjan province dry land wheat atlas by using climatic data and GIS. Journal of Water and Soil, (Agric.Sci. Technol.) 24(5): 894-907.

Karami, H., Maleki, A. \& Fathi, A. (2018). Determination effect of mycorrhiza and vermicompost on accumulation of seed nutrient elements in maize (Zea mays L.) affected by chemical fertilizer. J. Crop Nutr.Sci., 4(3): 1529.

Khatri-Chhetri, A., Aggarwal, P.K., Joshi, P.K. \& Vyas, S. (2017). Farmers' prioritization of climatesmart agriculture (CSA) technologies. Agric.Syst., 151: 184191, DOI: 10.1016/j.agsy.2016. 10.005

Khan, H. Z., Iqbal, S., Iqbal, A., Akbar, N. \& Jones, D. L. (2011). Response of maize (Zea mays L.) varieties to different levels of nitrogen. Crop Environ., 2(2): 15-19.

Koyro, H.-W., Lieth, H. \& Eisa, S. (2008). Salt tolerance of Chenopodium quinoa Willd., grains of the Andes: 
influence of salinity on biomass production, yield, composition of reserves in the seeds, water and solute relations. In book: Mangroves and Halophytes: Restoration and Utilisation, Springer, 133-145, DOI: 10.1007/978-1-4020-6720-4_13

Kozioł, M.J. (1992). Chemical composition and nutritional evaluation of quinoa (Chenopodium quinoa Willd.). J.Food Compost.Anal., 5(1): 35-68, DOI: 10.1016/0889-1575(92)90006-6

Kuljanabhagavad, T., Thongphasuk, P., Chamulitrat, W. \& Wink, M. (2008). Triterpene saponins from Chenopodium quinoa Willd. Phytochem., 69(9): 1919-1926, DOI: 10.1016/j.phytochem.2008.03.001

Li, H., Lei, P., Pang, X., Li, S., Xu, H., Xu, Z. \& Feng, X. (2017). Enhanced tolerance to salt stress in canola (Brassica napus L.) seedlings inoculated with the halotolerant Enterobacter cloacae HSNJ4. Appl. Soil Ecol., 119: 26-34, DOI: 10.1016/j.apsoil.2017.05.033

Lipper, L., Thornton, P., Campbell, B. M., Baedeker, T., Braimoh, A. \& Torquebiau, E.F. (2014). Climatesmart agriculture for food security. Nat.Clim.Change, 4: 1068-1072, DOI: 10.1038/nclimate243

Maradini Filho, A.M., Pirozi, M.R., Da Silva Borges, J.T., Pinheiro Sant'Ana, H.M., Paes Chaves, J.B. \& Dos Reis Coimbra, J.S. (2015). Quinoa: nutritional, functional and antinutritional aspects. Crit.Rev. Food Sci.Nutr., 57(8): 1618-1630, DOI: $\quad 10.1080 / 10408398.2014 .100$ 1811

Marschner, H. (2011). Marschner's Mineral Nutrition of Higher Plants. $3^{\text {rd }}$ Edition, Amsterdam, Netherlands: Elsevier/Academic Press, pp. 684, ISBN 978-0-12-384905-2.

Martínez, E.A., Veas, E., Jorquera, C., San Martín, R. \& Jara, P. (2009). Re-introduction of quínoa into arid Chile: cultivation of two lowland races under extremely low irrigation. J.Agron. Crop Sci.,195(1): 1-10,
DOI: 10.1111/j.1439-037X.2008.003 32. $x$

Mastebroek, H.D., Limburg, H., Gilles, T. \& Marvin, H.J.P. (2000). Ocurrence of sapogenins in leaves and seeds of quinoa (Chenopodium quinoa Willd.). J.Sci Food Agric., 80: 152-156.

Matiacevich, S.B., Castellión, M.L., Maldonado, S.B. \& Buera, M.P. (2006). Water-dependent thermal transitions in quinoa embryos. Thermochim. Acta, 448(2): 117-122 , DOI: 10.1016/j.tca.2006.06.016

Medina-Meza, I.G., Aluwi, N.A., Saunders, S.R. \& Ganjyal, G.M. (2016). GC-MS profiling of triterpenoid saponins from 28 quinoa varieties (Chenopodium quinoa Willd.) grown in Washington State. J.Agric.Food Chem., 64(45): 85838591, DOI: 10.1021/acs.jafc.6b0 2156

Miller, G., Suzuki, N., Ciftci-Yilmaz, S. \& Mittler, R. (2010). Reactive oxygen species homeostasis and signalling during drought and salinity stresses. Plant Cell.Environ., 33(4): 453-467, DOI: $\quad 10.1111 / \mathrm{j} .1365-3040.2009 .02$ 041.x

Mosseddaq, F.B., Bounsir, M.A., Khallouqand, O. \& Benlhabib, H. (2016). Optimization of quinoa nitrogen nutrition under mediterranean climatic conditions. In: International Quinoa Conference, 6-8 Dec., Dubai.

Mundigler, N. (1998). Isolation and determination of starch from amaranth (Amaranthus cruentus) and quinoa (Chenopodium quinoa). Starch/Stärke, 50(2-3): 67-69.

Munns, R. \& Gilliham, M. (2015). Salinity tolerance of crops - what is the cost? New Phytol., 2015, 208, 668-673, DOI: 10.1111/nph.13519

Navruz-Varli, S. \& Sanlier, N. (2016). Nutritional and health benefits of quinoa (Chenopodium quinoa Willd.). Journal of J. Cereal Sci., 69: 371-376, DOI: 10.1016/j.jcs.2016. 05.004 


\section{A. FATHI, F. KARDONI}

Oelke, E.A., Puntnam, D.H. Teynor, T.M.

\& Oplinger, E.S. (1992). Alternative Field Crops Manual, Quinoa. University of Wisconsin Extension, Cooperative Extension. http:Ilwww. hort.purdue.edulnewcroplafcmlquino a.

Peterson, A. \& Murphy, K.M. (2015). Quinoa cultivation for temperate North America: considerations and areas for investigation. In: Murphy, K.M., Matanguihan, J. (Eds.), Quinoa: Improvement and Sustainable Production. 1st ed. John Wiley \& Sons, Inc, Hoboken, NJ, pp. 173-192.

Präger, A., Munz, S., Nkebiwe, P.M., Mast, B. \& Graeff-Hönniger, S. (2018). Yield and quality characteristics of different quinoa (Chenopodium quinoa Willd.) cultivars grown under field conditions in southwestern Germany. Agron., 8(10): 197., DOI: 10.3390/agronomy 8100197

Pulvento, C., Riccardi, M., Lavini, A., lafelice, G., Marconi, E. \& d'Andria, R. (2012). Yield and quality characteristics of quinoa grown in open field under different saline and non-saline irrigation regimes. J.Agron. Crop Sci., 198: 254-263, DOI: 10.1111/j.1439-037X. 2012.00509.x

Ranhotra, G., Gelroth, J., Glaser, B., Lorenz, K. \& Johnson, D. (1993). Composition and protein nutritional quality of quinoa. Cereal Chem., 70(3): 303-305.

Razzaghi, F., Ahmadi, S.H., Adolf, V.I., Jensen, C.R., Jacobsen, S.E. \& Andersen, M.N. (2011). Water relations and transpiration of quinoa (Chenopodium quinoa Willd.) under salinity and soil drying. J.Agron.Crop Sci., 197(5): 348-360, DOI: 10. 1111/j.1439-037X.2011.00473.x

Repo-Carrasco, R., Espinoza, C. \& Jacobsen, S.E. (2003). Nutritional value and use of the Andean crops quinoa (Chenopodium quinoa) and kañiwa (Chenopodium pallidicaule).
Food Rev.Int., 19(1-2): 179-189, DOI: $10.1081 / \mathrm{FRI}-120018884$

Rojas, W., Pinto, M., Alanoca, C., Gómez-Pando, L., León-Lobos, P., Alercia, A., Diulgheroff, S., Padulosi, S. \& Bazile, D. (2015). Quinoa genetic resources and ex situ conservation, In book: State of the art report on quinoa around the world in 2013, Chapter: Quinoa genetic resources and ex situ conservation, Publisher: FAO/ CIRAD, pp. 56-82, Eds: Bazile Didier, Bertero Hector Daniel, Nieto Carlos.

Ruales, J. \& Nair, B.M. (1994). Properties of starch and dietary fibre in raw and processed quinoa (Chenopodium quinoa, Willd) seeds. Plant Food Hum.Nutr., 45(3): 223-246, DOI: 10.1007/bf01094092

Ruiz, K.B., Biondi, S., Martínez, E.A., Orsini, F., Antognoni, F. \& Jacobsen, S.-E. (2016). Quinoa - a model crop for understanding salttolerance mechanisms in halophytes. Plant Biosyst., 150(2): 357-371, DOI: 10.1080/11263504. 2015.1027317

Ruiz-Carrasco, K., Antognoni, F., Coulibaly, A.K., Lizardi, S., Covarrubias, A., Martínez, E.A. \& Zurita-Silva, A. (2011). Variation in salinity tolerance of four lowland genotypes of quinoa (Chenopodium quinoa Willd.) as assessed by growth, physiological traits, and sodium transporter gene expression. Plant Physiol.Biochem., 49(11): 1333-1341, DOI: 10.1016/j.plaphy. 2011.08.005

Schlick, G. \& Bubenheim, D.L. (1993). Quinoa: An emerging new crop with potential for CELSS. Available online:https://ntrs.nasa.gov/archive/n asa/casi.ntrs.nasa.gov/19940015664 .pdf (accessed on 21 September 2019).

Schoenlechner, R., Drausinger, J., Ottenschlaeger, V., Jurackova, K. \& Berghofer, E. (2010). Functional properties of gluten-free pasta 
produced from amaranth, quinoa and buckwheat. Plant foods for human nutrition. 65(4): 339-349, DOI:10.1007/s11130-010-0194-0

Schulte-auf'm-Erley, G., Kaul, H.P., Kruse, M. \& Aufhammer, W. (2005). Yield and nitrogen utilization efficiency of the pseudocereals amaranth, quinoa and buckwheat under differing nitrogen fertilization. Eur.J.Agron., 22(1): 95-100, DOI: 10.1016/j.eja.2003.11.002

Semenov, M.A., Jamieson, P.D. \& Martre, P. (2007). Deconvoluting nitrogen use efficiency in wheat: a simulation study. Eur.J.Agron., 26(3): 283-294, DOI: 10.1016/j.eja. 2006.10.009

Sharma, P., Jha, A.B., Dubey, R.S. \& Pessarakli, M. (2012). Reactive oxygen species, oxidative damage, and antioxidative defense mechanism in plants under stressful conditions. J.Bot., 1-27., DOI: 10.11 55/2012/217037

Singh, B. \& Kaur, A. (2018). Control of insect pests in crop plants and stored food grains using plant saponins: a review. $L W T$, 87: 93101, DOI: 10.1016/j.Iwt.2017.08.077

Sparg, S.G., Light, M.E. \& van Staden, J. (2004). Biological activities and distribution of plant saponins. J.Ethnopharmacol., 94(2-3): 219243, DOI: 10.1016/j.jep.2004.05.016

Steenwerth, K.L., Hodson, A.K., Bloom, A.J., Carter, M.R., Cattaneo, A. \& Jenkins, B.M. (2014). Climate-smart agriculture global research agenda: scientific basis for action. Agric. Food Sec., 3(1): 1-11, DOI: 10.1186/ 2048-7010-3-11

Stikic, R., Glamoclija, D., Demin, M., Vucelic-Radovic, B., Jovanovic, Z., Milojkovic-Opsenica, D. \& Milovanovic, M. (2012). Agronomical and nutritional evaluation of quinoa seeds (Chenopodium quinoa Willd.) as an ingredient in bread formulations. $J$. Cereal Sci., 55(2): 132-138, DOI: 10.1016/j.jcs.2011.10.010
Sun, Y., Lindberg, S., Shabala, L., Morgan, S., Shabala, S. \& Jacobsen, S.E. (2017). A comparative analysis of cytosolic $\mathrm{Na}+$ changes under salinity between halophyte quinoa (Chenopodium quinoa) and glycophyte pea (Pisum sativum). Environ.Exp.Bot., 141: 154-160, DOI: 10.1016/j.envexpbot. 2017.07.003

Tang, H., Watanabe, K. \& Mitsunaga, T. (2002). Characterization of storage starches from quinoa, barley and adzuki seeds. Carbohydr.Polym., 49(1): 13-22, DOI: 10.1016/s01448617(01)00292-2

Tilman, D., Balzer, C., Hill, J. \& Befort, B.L. (2011). Global food demand and the sustainable intensification of agriculture. Proceedings of the National Academy of Sciences United States of America, 108(50): 20260-202624, DOI: 10.1073/pnas. 1116437108

USDA U.S. Department of Agriculture, Agricultural Research Service. (2005). USDA National Nutrient Database for Standard Reference, Release 18. Nutrient Data Laboratory Home Page, http://www.nal.usda.gov/fnic/foodco $\mathrm{mp}$

Vacher, J.J. (1998). Responses of two main Andean crops, quinoa (Chenopodium quinoa Willd) and papa amarga (Solanum juzepczukii Buk.) to drought on the Bolivian Altiplano: significance of local adaptation. Agric.Ecosyst. \& Environ., 68(1-2): 99-108, DOI: 10.1016/S0167-8809(97)00140-0

Valencia-Chamorro, S.A. (2003). Quinoa. In: Caballero B. (Ed.), Encyclopedia of Food Science and Nutrition, Academic Press, Waltham, pp. 4895-4902, DOI: 10.1016/B0-12-22 7055-X/00995-0

Vega-Gálvez, A., Miranda, M., Vergara, J., Uribe, E., Puente, L. \& Martínez, E.A. (2010). Nutrition facts and functional potential of quinoa (Chenopodium quinoa willd.), 


\section{A. FATHI, F. KARDONI}

an ancient Andean grain: a review. J.Sci.Food Agric., 90(15): 25412547. ,DOI: 10.1002/jsfa.4158

Williams, J. \& Brenner, D. (1995). Grain amaranth, pp. 129-186. In: J. Williams (Ed.), Cereal and Pseudocereal, Chapman and Hall, London, UK.

Wilson, C., Read, J.J. \& Abo-Kassem, E. (2002). Effect of mixed-salt salinity on growth and ion relations of a quinoa and a wheat variety. $J$. Plant Nutr., 25(12): 2689-2704, DOI: 10.1081/PLN-120015532

Wright, K., Pike, O., Fairbanks, D. \& Huber, C. (2002). Composition of Atriplex hortensis, sweet and bitter Chenopodium quinoa seeds. J. Food Sci., 67(4): 1380-1383, DOI: 10.1111/j.1365-2621.2002.tb10294.x

Xu, H., Huang, X., Zhong, T., Chen, Z. \& Yu, J. (2014). Chinese land policies and farmers' adoption of organic fertilizer for saline soils, Land Use
Policy, 38: 541-549, DOI: 10.1016/ j.landusepol.2013.12.018

Zhao, D., Reddy, K.R., Kakani, V.G., Read, J.J. \& Carter, G.A. (2003). Corn (Zea mays L.) growth, leaf pigment concentration, photosynthesis and leaf hyperspectral reflectance properties as affected by nitrogen supply. Plant Soil, 257(1): 205-218, DOI: 10.1023/ A:1026233732507

Zeidali, E., Naseri, R., Mirzaei, A., Fathi, A. \& Darabi, F. (2018). Effect of different fertilizers on agrophysiological characteristics and weed density of maize. Plant Ecophysiol., 10(32): 198-214.

Zurita-Silva, A., Fuentes, F., Zamora, P., Jacobsen, S.-E. \& Schwember, A.R. (2014). Breeding quinoa (Chenopodium quinoa Willd.): potential and perspectives. Mol. Breed., 34(1): 13-30, DOI: 10.1007/ s11032-014-0023-5 